\title{
The Effects of Different Tillage Systems and Cultivars on Growth, Yield and Quality of Zucchini (Cucurbita pepo L.) in a Semi-Arid Sub-Tropical Environment
}

\author{
Phiwokwakhe A. Dlamini ${ }^{1}$, Michael T. Masarirambi ${ }^{1}$, Paul K. Wahome ${ }^{1}$ \& Mfanzile A. Dzimba ${ }^{1}$ \\ ${ }^{1}$ Department of Horticulture, Faculty of Agriculture, University of Eswatini, P.O. Luyengo M205, Eswatini \\ Correspondence: Department of Horticulture, Faculty of Agriculture, University of Eswatini, P.O. Luyengo \\ M205, Eswatini. E-mail: mike@uniswa.sz
}

Received: July 26, 2019

Accepted: August 9, 2019 Online Published: September 19, 2019

doi:10.5539/jps.v8n2p49

URL: https://doi.org/10.5539/jps.v8n2p49

\begin{abstract}
Conservation agriculture is a concept for resource-saving agricultural crop production system that serves to achieve acceptable profits and sustaining production while conserving the environment. The popularity of zucchini also known as baby marrow in the Kingdom of Eswatini has increased in recent years specifically for its economic value in the foreign market. This study was carried out at Malkerns Research Station, Malkerns in the Middleveld of the Kingdom of Eswatini to assess the effectiveness of different tillage methods and cultivars on growth, yield and quality of zucchini. The tillage methods used were zero, basin and mulch tillage. Furrow tillage was used as a control. The results showed that tillage methods had significant $(\mathrm{P}<0.05)$ differences in growth and yield of zucchini. Minimum tillage plants exhibited lowest number of leaves (9.5), vine length (36.4 $\mathrm{cm}$ ), leaf area index (2.5) and number of flowers (6), number of fruits (1.3) and marketable yield/plant (4.6 ton/ha). Non-significant $(\mathrm{P}>0.05)$ differences were obtained from plants grown under basin, mulch and furrow tillage. The highest vine length $(69.6 \mathrm{~cm})$, leaf number (17.0), LAI (3.6), and marketable yield (15.7 ton/ha) were obtained in zucchini plants grown under basin tillage system. However, there were no significant $(\mathrm{P}>0.05)$ differences in accumulation in leaves of zucchini plants of mineral content. In terms of the cultivars there were no significant $(\mathrm{P}>0.05)$ differences in vegetative growth. Star 8023 showed superiority in terms of number of fruits and marketable yield. It was observed that minimum tillage was less suitable in zucchini production as compared to other tillage systems. For higher production in zucchini, basin, furrow and mulch may be used. The best cultivar to use is star 8023 .
\end{abstract}

Keywords: conservation agriculture, zucchini, leaf area index, cultivar, vine length, tillage system

\section{Introduction}

The use of conservation farming has gained momentum in recent years. This is attributed mainly because the Food and Agriculture Organisation (FAO) has been actively promoting Conservation Agriculture (CA) especially in the developing and emerging economies (Hebblethwaite et al., 1996). It holds a tremendous potential for all size of farms and agro-ecological systems, but its adoption is perhaps mostly urgently required by small scale farmers (African Conservation Tillage Network, 2008), especially those facing acute labour shortages. It is a way of combining profitable agricultural production with environmental concerns and sustainability and it has been proven to work in a variety of agro-ecological zones and farming systems. It is being perceived by practitioners as a valid tool for Sustainable Land Management (SLM) (Fowler and Lockstrom, 2001).

Conventional 'arable' agriculture is normally based on soil tillage as the main operation. The most widely known tool for this operation is the plough which has become a symbol for agriculture (Tittonell et al., 2008). Soil tillage in the past has been associated with increased fertility, which originates from the mineralisation of soil nutrients as a consequence of tillage. This process leads to long term reduction of soil organic matter. According to FAO (2008a), soil organic matter not only provides nutrients for the crop, but it is also a critical element for the stabilisation of soil structure. Therefore, most soils degrade under prolonged intensive arable agriculture. This structural degradation of soil results in the formation of crust and compact and lead to soil erosion (Abdalla and Mohamed, 2007). Excessive tillage of agricultural soils results in short term increase in fertility but will degrade soil in the medium term. Structural degradation, loss of organic matter, erosion and failing biodiversity 
are to be expected (Gupta et al., 2007).

Zero-tillage was born out of a necessity to combat soil degradation and has been widely adopted by farmers of different scale in North and South America (Bolliger et al., 2006: Triplett and Warren, 2008). Brazil's "Zero-tillage revolution", in particular, is viewed as an attractive potential solution to reversing soil degradation and increasing land productivity in South America (Fowler and Lockstrom 2001; Hobbs, 2007). Zero-tillage, together with crop residue management (mulches) and crop rotation are the pillars of CA as it is now actively promoted by a growing number of research and extension programmes, supported by major international initiatives e.g. FAO; the Direct-sowing Mulch-based Conservation Agriculture (DMC)-systems initiative under the Global Forum on Agricultural Research (GFAR), and the European Conservation Agriculture Federation (ECAF). (Benites and Ashbuner, 2003; FAO, 2008b). Yet, apart from a few recent articles (Erenstein, 2002; 2003; Bolliger et al., 2006; Affholder and Jourdain, 2008; Lahmar, 2009), it appears that CA has escaped critical analysis. The more critical publications address pertinent issues such as: (a) Principles of CA, and conditions, actually contribute to the effects sought; (b) The trade-offs of implementing CA; (c) The need identified by the farmer or one mainly identified by scientists and policymakers; and (d) The preconditions for adoption by smallholder farmers that exist in Sub-Saharan Africa (Bolliger et al., 2006; Bolliger, 2007; Gowing and Palmer, 2008).

Since the adoption of CA in 2002 by the Cooperation for the Development of Emerging Countries (COSPE) and FAO, there has been a change in the way people react towards the adoption of CA in Swaziland (Oladeebo, 2013) The introduction of Conservation Agriculture in Eswatini began in 2002 and was intended to alleviate food shortages and ensure food security among the less privileged rural households. This move was a response to the frequent drought, crop failures and land degradation especially in areas with poor soils (Oladeebo, 2013). A preliminary survey by Mlipha (2010) showed low levels of crop productivity in Shewula, Kingdom Swaziland due to soil erosion, mono-cropping with maize and vulnerability to draught. Shewula was therefore selected to be one of the pilot sites for CA (Mlipha, 2010). Over the years, FAO continued expanding and up scaling the promotion of CA on Swazi Nation Land (SNL). One of the beneficiaries of the CA up scaling programme was the Ngwempisi Rural Development Area (RDA). The CA was introduced in Ngwempisi RDA in the year 2007 (Oladeebo. 2013).

The popularity of baby marrow in Eswatini has developed in the recent past not specifically for its consumption but for its economic value in the foreign markets. Baby vegetable business in Eswatini is envisaged to earn at least US\$4 million in foreign exchange, provide employment opportunities and market for local vegetable farmers (NAMBoard, 2016).

The Kingdom of Eswatini is one of the countries that is greatly affected by soil erosion which is the removal of top soil due to heavy rainfall on land that is not protected by a layer of mulch (FAO, 2001). Tilling of the soil is a practice done in conventional agriculture, greatly promoting soil erosion and crusting of soils because it loosens the soil making it vulnerable to soil erosion thus promoting soil degradation and a decrease in soil fertility. Soil tillage is also responsible for destroying organic matter that is provided within the soil cover, mineral loss and water loss within the soil. Tillage of the ground in preparation of agricultural crops in Eswatini requires more money from the farmer due to purchase of fuel for tractors or feed for draught animals. A lot of labour is also needed to carry out and manage the tilling activity. The majority of farmers in Eswatini lack the adequate funds for soil preparation thus leading to a reduction in crop production and an increase in hunger and poverty. Crop production ends up being expensive for the majority of Swati farmers thus leading them not to produce to their utmost capabilities.

The recent shift in economic focus is bringing many investors, both young and old, to the agricultural sector of the economy (Agriculture and Food partnership, 2016). Therefore, there is a need to expose the farmers to as many profitable production technologies in agriculture as possible. One of these areas is the production of vegetables, especially the exotic ones. It is an area which is commanding a lot of attention in the agricultural sector because exotic vegetables are in high demand, and often requested for in places like big shopping malls, international hotels, multinational fast-food chains and high profile societies. They are also seemingly attractive to new farming entrants because they have short production periods and high economic returns on investment (Teresa and Harry, 2016).

Some of these vegetables are already widely known and utilised. In fact, research, according to Hassayon (2009) has also shown the health benefits of some of them. Lettuce (Latuca sativa L.) for instance, is known to prevent osteoporosis, iron deficiency and believed to protect man from cardiovascular diseases. However, there are still some exotic vegetables which are of high economic value but less known among Swati farmers. A good example 
of such is zucchini. Zucchini, also known as courgette, is one of the most popular summer squashes in the United States of America (USA) and Europe (Hassayon, 2009).

Despite the benefits/values of zucchini crop, there is scarcity of documented information about the crop in the Kingdom of Eswatini. In addition, awareness about the crop is still very low. There is therefore a need to have adequate information on the cultivation of such a crop more especially the tillage types and the type of cultivar/s, with a view to documenting such for wider dissemination among potential and existing Swati farmers.

The main objective of the study was to contribute to nutritional and food security in the Kingdom of Eswatini. The specific objectives of the study were to: (1) assess the effects of soil tillage on growth, yield and quality of baby marrow and (2) determine the effect of cultivar on growth, yield and quality of baby marrow.

\section{Materials and Methods}

\subsection{Experimental Site}

The experiment was carried out at the Malkerns Research Station, Kingdom of Eswatini in the Horticultural Crop Department, Malkerns, between September 2017 and March 2018. The site is located at Malkerns, Manzini Region, in the Middleveld agro-ecological zone, 26 $34^{\prime} \mathrm{S}$ and $31^{\circ} 19^{\prime} \mathrm{E}$, and the average altitude of this area is $750 \mathrm{~m}$ above sea level. The annual mean precipitation is $980 \mathrm{~mm}$ with most of the rain falling between October and March, with the average summer and winter temperatures of $27^{\circ}$ and $15^{\circ} \mathrm{C}$ respectively (Eswatini Meteorological Department, 2018). Table (1) shows weather data during the duration of the experiment.

Table 1. Weather data on rainfall, hours of sunshine and mean maximum and minimum temperatures for Malkerns Research Station for the period 3 of December 2017 to February 2018

\begin{tabular}{lllll}
\hline Month & $\begin{array}{l}\text { Total rainfall } \\
(\mathrm{mm})\end{array}$ & $\begin{array}{l}\text { Mean monthly } \\
\text { radiation }(\mathrm{h})\end{array}$ & $\begin{array}{l}\text { Mean maximum } \\
\text { temperature }\left({ }^{\circ} \mathrm{C}\right)\end{array}$ & $\begin{array}{l}\text { Mean minimum } \\
\text { temperature }\left({ }^{\circ} \mathrm{C}\right)\end{array}$ \\
\hline December 2017 & 46.8 & 12.1 & 29.8 & 20.0 \\
January 2018 & 18.2 & 12.0 & 32.3 & 23.6 \\
February 2018 & 31.1 & 11.8 & 28.5 & 19.5 \\
\hline
\end{tabular}

Source: Eswatini Meteorological Department (2018)

\subsection{Experimental Design}

The experiment was laid in a Split Plot Design. The cultivars were assigned to the main plots and the tillage systems to the sub-plots. There were three cultivars used; Star 8023, Hy-green Baby marrow and Star 8021. There were four tillage system treatments: Basin tillage (small earthen dams of $20 \mathrm{~cm}$ diameter), Mulch (at least $30 \%$ of the soil surface covered with plant residue after planting), minimum tillage (soil surface was left untilled only planting hole of $8 \mathrm{~cm}$ diameter was drilled) and for the control the soil was tilled to $30 \mathrm{~cm}$ depth (conventional method) using forks and ridges were opened. The treatments were replicated three times. The zucchini seeds were planted directly to the field on the $21^{\text {st }}$ December, 2017. Each plot was $3 \mathrm{~m}$ by $3 \mathrm{~m}$ with a pathway of $1 \mathrm{~m}$ between each plot. The gross experimental area was $47 \mathrm{~m}$ by $15 \mathrm{~m}\left(705 \mathrm{~m}^{2}\right)$ and the net experimental area was $36 \mathrm{~m}$ by $12 \mathrm{~m}\left(402 \mathrm{~m}^{2}\right)$. There were a total of 36 plots, each plot with dimensions $3 \times 3 \mathrm{~m}$ $\left(9 \mathrm{~m}^{2}\right)$. Plant spacing was $1.2 \mathrm{~m}$ between rows and $0.4 \mathrm{~m}$ between plants. The usual cultural practices were observed to ensure that an even stand of plants was established in the field plots. Some chemical and physical properties of the soil were investigated as illustrated in Table (2)

Table 2. Physical and chemical characteristics of the soil used in the experiment

\begin{tabular}{lllll}
\hline Soil & $\mathrm{pH}$ & Exchangeable acidity me/100g & Phosphorus $(\mathrm{P})(\mathrm{mg} / \mathrm{kg})$ & Potassium $(\mathrm{K})(\mathrm{mg} / \mathrm{kg})$ \\
\hline Loamy & 5.4 & 0.41 & 1658 & 1764 \\
\hline
\end{tabular}

\subsection{Fertilization}

The plants were applied with NPK (2-3-2 (37)) fertilizer at a rate of $955 \mathrm{~kg} / \mathrm{ha}$, LAN was used for side dressing applied in one application at a rate of $100 \mathrm{~kg} / \mathrm{ha}$ at the flowering stage. The treatments were irrigated with a sprinkle irrigation system which supplied water throughout the growing season with a mean application volume of $100 \mathrm{~cm}^{3}$ per plant after every two days in the early hours of morning (between 7 and $8 \mathrm{am}$ ). Plants were sprayed on a weekly basis to prevent damage by insect pests and diseases, using Bravo (Syngenta, Midrand, South Africa) and Decis (Forte, Bayer (Pty) Ltd, South Africa). Weed control was achieved through hand cultivation of the trial plots. 


\subsection{Plant Material}

The zucchini cultivars Star 8021, Star 8023 and Hy-green seed were obtained from NAMBoard, Matsapha, Eswatini.

\subsection{Data Collection}

\subsubsection{Vegetative Growth}

Data was collected two weeks after planting (WAP) and at one week intervals. The data collected included; plant height, number of leaves, leaf area index (LAI) calculated, marketable yield (mass), nutrient composition (calcium and iron) of fresh baby marrow (leaf tissue analysis) and dry mass per $100 \mathrm{~g}$ consumable product. Data were collected on five plants randomly selected from each plot. The vine length was measured using a meter ruler from the base to the longest vine. This was done weekly from the second to the fifth WAP. Number of leaves, flowers and fruits were determined by manual counting on weekly basis. However, flowers were counted from the fourth to the seventh WAP. Fruits were counted from the fourth to eighth week after planting when they had started to form. For LAI randomly selected leaves were picked from the sampled plants once to avoid plant disturbance on the sixth WAP. The leaf area was measured by using a graph paper with grid squares, each measuring $1 \times 1 \mathrm{~cm}$. The LAI was then calculated by multiplying the average number of leaves of each treatment by the average leaf area to get the canopy area and then divided by the plant ground area (canopy area $\mathrm{cm}^{2} / \mathrm{plant}$ ground area $\mathrm{cm}^{2}$ ) (Xiaolei and Zhifeng, 2004)

\subsubsection{Fruit Yield and Quality}

For marketable yield, fruits from each sampled plant were harvested and their masses were determined immediately from fourth to eighth WAP. Their masses were measured using the electronic mass scale. For dry mass determination, the oven method was used. Samples of $100 \mathrm{~g}$ plant of edible (fruit) product were obtained from each treatment and fresh mass obtained followed by drying in an oven at $45^{\circ} \mathrm{C}$ for 24 hours and the dry mass was then measured (Ewansiha et al., 2015).

\subsubsection{Mineral Contents}

For mineral content analysis of leaf tissues, a microwave was used for digestion of zucchini plant tissue. A sample of $0.5 \mathrm{~g}$ of each treatment was weighed and put in the microwave bomb. For calcium $(\mathrm{Ca})$ analysis, $10 \mathrm{ml}$ $6 \mathrm{M} \mathrm{HCl}$ and $10 \mathrm{ml} 6 \mathrm{M} \mathrm{HNO}_{3}$ were used for digestion. For iron (Fe) analysis, $10 \mathrm{ml} \mathrm{H}_{2} \mathrm{SO}_{4}$ and $10 \mathrm{ml} 6 \mathrm{M}$ $\mathrm{HNO}_{3}$ were used for digestion. The acids were added into the bombs containing the samples and digested in the microwave for two minutes. The samples were then cooled to room temperature and filtered into $50 \mathrm{ml}$ volumetric flasks. Dilution to the mark was done using deionized water. Standard solutions of 0.5, 1.0, 1.5 and $2.0 \mathrm{ppm}$ were prepared from a 1,000 ppm stock solution of $\mathrm{Ca}$ and Fe using the formula: $\mathrm{C} 1 \mathrm{~V} 1=\mathrm{C} 2 \mathrm{~V} 2$. With a known concentration (C2) and volume (V2) required, the volume of $1000 \mathrm{ppm}$ stock solution was calculated and made necessary dilutions to make V2. Standards were run in the atomic absorption spectrometer (AAS) to determine their absorbance from which calibration curves were plotted. The operating parameters for AAS are shown (Table 3) (Gaj et al., 2015).

Table 3. Operating parameters for atomic absorption spectrometer

Source: Gaj et al., (2015)

\begin{tabular}{lll}
\hline Parameter & $\mathrm{Fe}$ & $\mathrm{Ca}$ \\
\hline Wave length (khz) & 243.6 & 421.1 \\
Slit width (nm) & 2.0 & 0.5 \\
Lamp current (mA) & 30 & 10 \\
\hline
\end{tabular}

\subsection{Data Analysis}

Data collected was subjected to analysis of variance (ANOVA) using Statistical Analysis Software (SAS) statistical package (SAS, 2013). Mean separation test at $\mathrm{P}=0.05$ was done using the Duncan's New Multiple Range Test (DNMRT) where significant differences existed (Gomez and Gomez, 1984).

\section{Results}

\subsection{Vegetative Growth}

\subsubsection{Vine Length}

There were significant $(\mathrm{P}<0.05)$ differences in vine length amongst the treatments (Table 4). In cultivar Star 
8023, the highest vine length $(64.4 \mathrm{~cm})$ at 5 WAP was observed in plants under basin till while the lowest (36.4 $\mathrm{cm}$ ) was obtained from plants grown in minimum tillage system. The second highest vine length was obtained from zucchini plants under mulch system. The vine length of plants grown in basin till system was almost twice as much as those from minimum tillage. For the cultivar Star 8021, the highest vine length $(69.6 \mathrm{~cm})$ at 5 WAP was observed in plants grown under furrow tillage while minimum tillage had the lowest $(36.8 \mathrm{~cm})$. The second highest vine length was obtained in plants grown in both basin and mulch tillage systems. In cultivar Hy-green, the highest vine length $(63.0 \mathrm{~cm})$ at 5 WAP was obtained in plants under basin tillage while the lowest $(36.8 \mathrm{~cm})$ was observed in plants under minimum tillage system.

Table 4. Effects of tillage system and cultivar on vine length (cm) of zucchini.

\begin{tabular}{|c|c|c|c|c|c|}
\hline \multirow[t]{2}{*}{ Tillage systems } & & \multicolumn{4}{|c|}{ Weeks after planting } \\
\hline & & 2 & & 4 & 5 \\
\hline Star 8023 & \multicolumn{4}{|c|}{ Vine length $(\mathrm{cm})$} & \\
\hline Mulch tillage system & $32.5 b$ & $46.3 \mathrm{a}$ & $55.9 \mathrm{~b}$ & $60.6 \mathrm{a}$ & \\
\hline Minimum tillage system & $27.2 \mathrm{c}$ & $27.3 \mathrm{~b}$ & $28.3 \mathrm{c}$ & $36.4 \mathrm{c}$ & \\
\hline Basin tillage system & $37.0 \mathrm{a}$ & $49.2 \mathrm{a}$ & $63.1 \mathrm{~b}$ & $64.4 \mathrm{a}$ & \\
\hline $\begin{array}{l}\text { Furrow tillage system } \\
\text { Star } 8021\end{array}$ & $30.1 b$ & $44.5 \mathrm{a}$ & $52.0 \mathrm{a}$ & $55.6 \mathrm{~b}$ & \\
\hline Mulch tillage system & $34.8 \mathrm{a}$ & $57.1 \mathrm{a}$ & $62.5 \mathrm{a}$ & 63.6a & \\
\hline Minimum tillage system & $26.1 \mathrm{~b}$ & $29.6 \mathrm{c}$ & $29.8 \mathrm{~b}$ & $36.8 \mathrm{~b}$ & \\
\hline Basin tillage system & $34.4 \mathrm{a}$ & $49.2 b$ & $60.4 \mathrm{a}$ & $63.6 \mathrm{a}$ & \\
\hline $\begin{array}{l}\text { Furrow tillage system } \\
\text { Hy-green }\end{array}$ & $36.6 \mathrm{a}$ & $62.3 \mathrm{a}$ & $62.5 \mathrm{a}$ & $69.6 \mathrm{a}$ & \\
\hline Mulch tillage system & $36.2 \mathrm{a}$ & $48.1 \mathrm{a}$ & $57.9 \mathrm{a}$ & $60.8 \mathrm{a}$ & \\
\hline Minimum tillage system & $28.9 \mathrm{~b}$ & $29.8 \mathrm{c}$ & $30.3 b$ & $36.8 b$ & \\
\hline Basin tillage system & $37.1 \mathrm{a}$ & $52.3 \mathrm{a}$ & $62.5 \mathrm{a}$ & $63.0 \mathrm{a}$ & \\
\hline Furrow tillage system & $31.6 \mathrm{~b}$ & $45.1 \mathrm{~b}$ & $56.5 \mathrm{a}$ & $59.2 \mathrm{a}$ & \\
\hline
\end{tabular}

In a column means followed by the same letter are not significantly different from each other at $P=0.05$. Mean separation by DNMRT

\subsubsection{Number of Leaves}

The results showed that there were significant $(\mathrm{P}<0.05)$ differences in number of leaves amongst the treatments (Table 5). In cultivar Star 8023, the highest number of leaves (17.0) at 5 WAP was observed in plants under basin tillage system while the lowest (10.5) was obtained from plants grown in minimum tillage system. The second highest number of leaves was obtained from zucchini plants under mulch tillage system. Plants under furrow tillage system had almost twice the number of leaves as compared to those under minimum tillage. For the cultivar Star 8021, the highest number of leaves (18.1) at 5 WAP was observed in plants grown under mulch tillage while minimum tillage had the lowest (9.5). Zucchini plants under both basin and mulch systems obtained the second highest leaf number. In cultivar Hy-green, the highest leaf number (19.3) at 5 WAP was obtained in plants under basin tillage while the lowest (11.0) was observed in plants under minimum tillage system. Plants grown under mulch system had the second highest number of leaves. 
Table 5. Effects of tillage system and cultivar on number of leaves of zucchini.

\begin{tabular}{lllll}
\hline Tillage systems & \multicolumn{4}{c}{ Weeks after planting } \\
\cline { 2 - 5 } & 2 & 3 & 4 & 5 \\
\hline Star 8023 & & & & \\
\hline Mulch tillage system & $6.9 \mathrm{a}$ & $12.1 \mathrm{a}$ & $14.3 \mathrm{a}$ & $16.3 \mathrm{a}$ \\
Minimum tillage system & $5.1 \mathrm{c}$ & $7.9 \mathrm{~b}$ & $6.7 \mathrm{~b}$ & $10.5 \mathrm{~b}$ \\
Basin tillage system & $6.5 \mathrm{a}$ & $11.7 \mathrm{a}$ & $13.6 \mathrm{a}$ & $17.0 \mathrm{a}$ \\
Furrow tillage system & $5.9 \mathrm{~b}$ & $12.2 \mathrm{a}$ & $12.4 \mathrm{a}$ & $15.6 \mathrm{a}$ \\
Star 8021 & & & & \\
Mulch tillage system & $7.9 \mathrm{a}$ & $10.5 \mathrm{a}$ & $16.0 \mathrm{a}$ & $18.1 \mathrm{a}$ \\
Minimum tillage system & $4.8 \mathrm{~b}$ & $6.5 \mathrm{~b}$ & $7.1 \mathrm{~b}$ & $9.5 \mathrm{~b}$ \\
Basin tillage system & $7.8 \mathrm{a}$ & $9.7 \mathrm{a}$ & $16.0 \mathrm{a}$ & $16.1 \mathrm{a}$ \\
Furrow tillage system & $8.1 \mathrm{a}$ & $10.6 \mathrm{a}$ & $14.7 \mathrm{a}$ & $17.3 \mathrm{a}$ \\
Hy-green & & & & \\
Mulch tillage system & $8.9 \mathrm{a}$ & $9.3 \mathrm{a}$ & $11.9 \mathrm{a}$ & $19.1 \mathrm{a}$ \\
Minimum tillage system & $5.8 \mathrm{c}$ & $6.7 \mathrm{~b}$ & $3.9 \mathrm{~b}$ & $11.0 \mathrm{c}$ \\
Basin tillage system & $9.2 \mathrm{a}$ & $9.3 \mathrm{a}$ & $11.3 \mathrm{a}$ & $19.3 \mathrm{a}$ \\
Furrow tillage system & $7.7 \mathrm{~b}$ & $8.6 \mathrm{a}$ & $12.8 \mathrm{a}$ & $17.3 \mathrm{~b}$ \\
\hline
\end{tabular}

In a column means followed by the same letter are not significantly different from each other at $\mathrm{P}=0.05$. Mean separation by DNMRT

\subsubsection{LAI}

There were significant $(\mathrm{P}<0.05)$ differences in LAI amongst the treatments (Figure 1). In cultivar Star 8023, the highest LAI (3.5) at 5 WAP was observed in plants under mulch and basin tillage systems while the lowest (2.6) was obtained from plants grown in minimum tillage system. For the cultivar Star 8021, the highest LAI (3.6) at 5 WAP was obtained in plants grown under basin tillage while minimum tillage had the lowest (2.5). Plants under mulch systems had the second highest LAI. In cultivar Hy-green, the highest LAI (3.6) at 5 WAP was obtained in plants under basin tillage while the lowest (2.8) was observed in plants under minimum tillage system. Plants grown under mulch system had the second highest LAI.

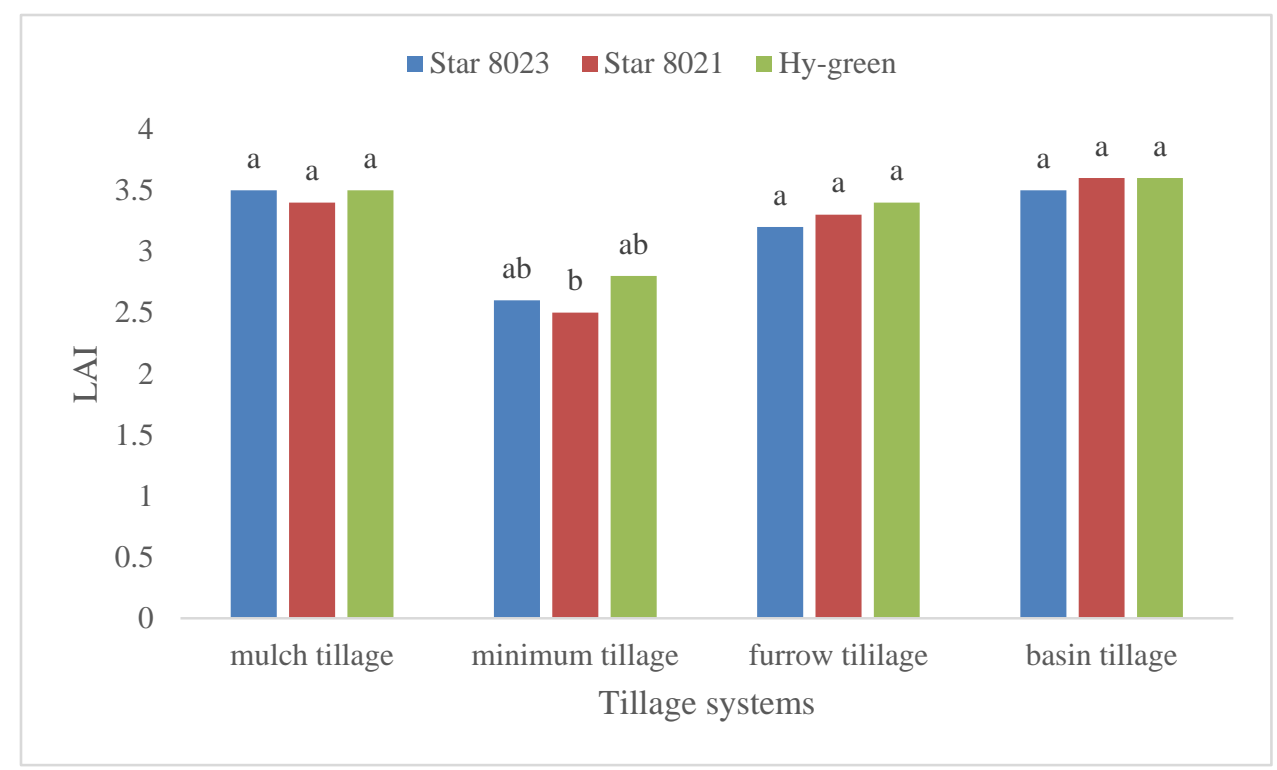

Figure 1. Effects of different tillage systems on LAI of zucchini cultivars Star 8023, Star 8021 and Hy-green. Bars for each parameter followed by same letter not significantly different from each other at $\mathrm{P}=0.005$. Mean separation by DNMRT 


\subsection{Flower and Fruit Numbers}

\subsubsection{Number of Flowers}

There were significant $(\mathrm{P}<0.05)$ differences in the number of flowers amongst treatments (Table 6). In cultivar Star 8023, the highest number of flowers (9.7) at 6 WAP was observed in plants under mulch system while the lowest (6.0) was obtained from plants grown in minimum tillage system. The second highest number of flowers was obtained from zucchini plants under basin tillage system. For the cultivar Star 8021, the highest number of flowers (9.8) at 6 WAP was observed in plants grown under furrow tillage while minimum tillage obtained the lowest (6.2). Plants under mulch system had the second highest flower number. In cultivar Hy-green, the highest flower number (10.8) at 6 WAP was obtained in plants under furrow tillage while the lowest (6.1) was observed in plants under minimum tillage system. Plants grown under mulch system had the second highest number of flowers. In all the cultivars the number of flowers tended to peak at 6 WAP.

Table 6. Effects of tillage system and cultivar on number of flowers of zucchini.

\begin{tabular}{lllll}
\hline Tillage systems & \multicolumn{5}{c}{ Weeks after planting } \\
\cline { 2 - 5 } & 4 & 5 & 6 & 7 \\
\hline Star 8023 & & & & \\
\hline Mulch tillage system & $4.5 \mathrm{a}$ & $5.2 \mathrm{~b}$ & $9.8 \mathrm{a}$ & $7.2 \mathrm{a}$ \\
Minimum tillage system & $1.9 \mathrm{c}$ & $4.2 \mathrm{c}$ & $6.0 \mathrm{~b}$ & $4.6 \mathrm{~b}$ \\
Basin tillage system & $2.6 \mathrm{~b}$ & $6.8 \mathrm{a}$ & $9.1 \mathrm{a}$ & $7.5 \mathrm{a}$ \\
Furrow tillage system & $3.9 \mathrm{a}$ & $5.5 \mathrm{~b}$ & $8.1 \mathrm{a}$ & $6.6 \mathrm{a}$ \\
Star 8021 & & & & \\
Mulch tillage system & $2.9 \mathrm{a}$ & $6.8 \mathrm{a}$ & $9.6 \mathrm{a}$ & $7.8 \mathrm{a}$ \\
Minimum tillage system & $1.8 \mathrm{~b}$ & $5.9 \mathrm{a}$ & $6.2 \mathrm{~b}$ & $4.7 \mathrm{~b}$ \\
Basin tillage system & $3.7 \mathrm{a}$ & $7.1 \mathrm{a}$ & $8.7 \mathrm{a}$ & $7.5 \mathrm{a}$ \\
Furrow tillage system & $3.0 \mathrm{a}$ & $7.1 \mathrm{a}$ & $9.7 \mathrm{a}$ & $7.9 \mathrm{a}$ \\
Hy-green & & & & \\
Mulch tillage system & $8.1 \mathrm{a}$ & $8.2 \mathrm{a}$ & $10.5 \mathrm{a}$ & $5.3 \mathrm{a}$ \\
Minimum tillage system & $5.6 \mathrm{~b}$ & $5.0 \mathrm{~b}$ & $6.1 \mathrm{~b}$ & $3.6 \mathrm{a}$ \\
Basin tillage system & $8.9 \mathrm{a}$ & $8.1 \mathrm{a}$ & $9.5 \mathrm{a}$ & $4.5 \mathrm{a}$ \\
Furrow tillage system & $8.7 \mathrm{a}$ & $8.1 \mathrm{a}$ & $10.8 \mathrm{a}$ & $5.2 \mathrm{a}$ \\
\hline
\end{tabular}

In a column means followed by the same letter are not significantly different from each other at $\mathrm{P}=0.05$. Mean separation by DNMRT

\subsubsection{Number of Fruits}

There were significant $(\mathrm{P}<0.05)$ differences in the number of fruits harvested per day per plant amongst the treatments. The lowest number of fruits was observed in zucchini plants grown under minimum tillage with the other treatments yielding almost equal number of fruits per day per plant (Table 7). In cultivar Star 8023, the highest number of fruits (6.9) per plant per day at 8 WAP was observed in plants under mulch till while the lowest (5.3) was obtained from plants grown in minimum tillage system. For the cultivar Star 8021, the highest number of fruits (2.8) per plant per day at $6 \mathrm{WAP}$ was observed in plants grown under mulch system while minimum tillage had the lowest (1.3). In cultivar Hy-green, the highest fruit number (3.3) at 6 WAP was obtained in plants under mulch while the lowest (1.4) was observed in plants under minimum tillage system. 
Table 7. Effects of tillage system and cultivar on number of fruits of zucchini.

\begin{tabular}{llllll}
\hline Tillage systems & \multicolumn{5}{c}{ Weeks after planting } \\
\cline { 2 - 6 } & 4 & 5 & 6 & 7 & 8 \\
\hline Star 8023 & & & & & \\
\hline Mulch tillage system & $1.1 \mathrm{~b}$ & $1.2 \mathrm{a}$ & $2.1 \mathrm{a}$ & $1.8 \mathrm{a}$ & $6.9 \mathrm{a}$ \\
Minimum tillage system & $2.5 \mathrm{a}$ & $1.0 \mathrm{a}$ & $1.6 \mathrm{~b}$ & $1.7 \mathrm{a}$ & $5.3 \mathrm{c}$ \\
Basin tillage system & $1.1 \mathrm{~b}$ & $1.7 \mathrm{a}$ & $2.5 \mathrm{a}$ & $1.8 \mathrm{a}$ & $6.5 \mathrm{a}$ \\
Furrow tillage system & $1.0 \mathrm{~b}$ & $1.5 \mathrm{a}$ & $1.9 \mathrm{a}$ & $2.2 \mathrm{a}$ & $5.9 \mathrm{~b}$ \\
Star 8021 & & & & & \\
Mulch tillage system & $1.0 \mathrm{a}$ & $1.1 \mathrm{a}$ & $2.8 \mathrm{a}$ & $2.6 \mathrm{a}$ & $2.2 \mathrm{a}$ \\
Minimum tillage system & $0.0 \mathrm{~b}$ & $0.0 \mathrm{~b}$ & $1.3 \mathrm{~b}$ & $1.0 \mathrm{~b}$ & $0.0 \mathrm{~b}$ \\
Basin tillage system & $1.5 \mathrm{a}$ & $1.0 \mathrm{a}$ & $2.7 \mathrm{a}$ & $2.3 \mathrm{a}$ & $2.0 \mathrm{a}$ \\
Furrow tillage system & $1.1 \mathrm{a}$ & $1.2 \mathrm{a}$ & $2.4 \mathrm{a}$ & $2.4 \mathrm{a}$ & $1.7 \mathrm{a}$ \\
Hy-green & & & & & \\
Mulch tillage system & $1.6 \mathrm{a}$ & $1.6 \mathrm{a}$ & $3.3 \mathrm{a}$ & $2.2 \mathrm{a}$ & $2.9 \mathrm{a}$ \\
Minimum tillage system & $0.0 \mathrm{~b}$ & $1.0 \mathrm{a}$ & $1.4 \mathrm{~b}$ & $1.3 \mathrm{~b}$ & $0.0 \mathrm{~b}$ \\
Basin tillage system & $1.5 \mathrm{a}$ & $1.4 \mathrm{a}$ & $3.1 \mathrm{a}$ & $2.8 \mathrm{a}$ & $2.9 \mathrm{a}$ \\
Furrow tillage system & $1.3 \mathrm{a}$ & $1.1 \mathrm{a}$ & $3.0 \mathrm{a}$ & $2.4 \mathrm{a}$ & $3.3 \mathrm{a}$ \\
\hline
\end{tabular}

In a column means followed by the same letter are not significantly different from each other at $P=0.05$. Mean separation by DNMRT

\subsection{Fruit Yield and Quality}

There were significant $(\mathrm{P}<0.05)$ differences in marketable yield amongst the treatments. The lowest marketable yield of zucchini plants was observed in plants under minimum tillage and the trend was consistent across the three cultivars (Figure 2). In cultivar Star 8023, the highest marketable yield (15.2 ton/ha) was obtained in plants under basin tillage while the lowest (5.1 ton/ha) was obtained from plants grown in minimum tillage system. The second highest marketable yield was obtained from zucchini plants under mulch system. For the cultivar Star 8021, the highest marketable yield (13.6 ton/ha) obtained in plants grown under mulch system while minimum tillage had the lowest (4.4 ton/ha). Plants under basin tillage system had the second highest marketable yield. In cultivar Hy-green, the highest marketable yield (14.7 ton/ha) at 6 WAP was obtained in plants under mulch while the lowest $(8.3 \mathrm{ton} / \mathrm{ha}$ ) was observed in plants under zero tillage system. Plants grown under basin tillage system had the second highest marketable yield. There were no significant $(\mathrm{P}>0.05)$ differences in dry mass of zucchini edible fruit parts amongst the tillage treatments (Figure 3). Similarly there was also no significant $(P>0.05)$ differences in dry mass of zucchini amongst cultivars.

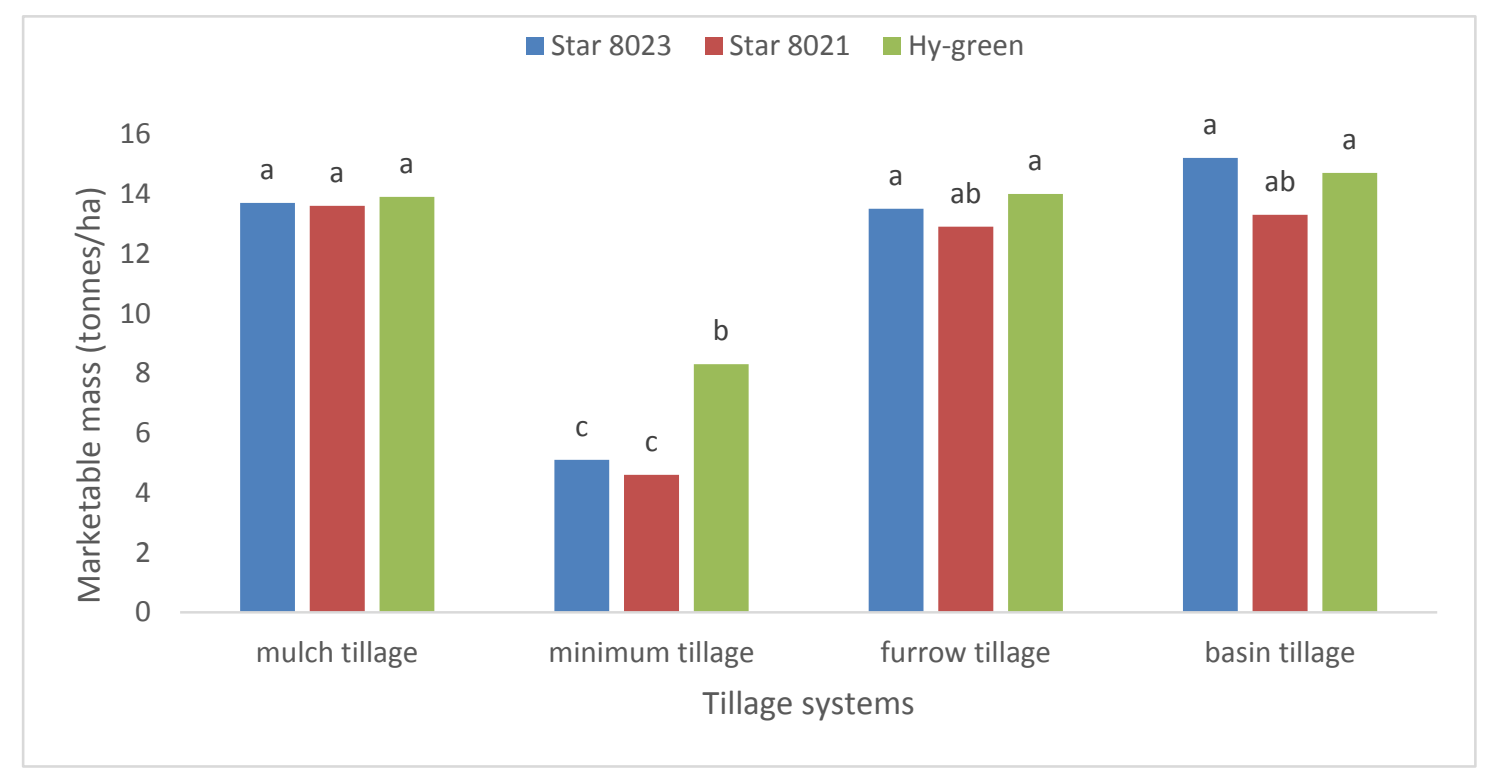


Figure 2. Effects of different tillage systems on marketable yield of zucchini cultivars Star 8023, Star 8021 and Hy-green. Bars for each parameter followed by same letter not significantly different from each other at $\mathrm{P}$ $=0.005$. Mean separation by DNMRT

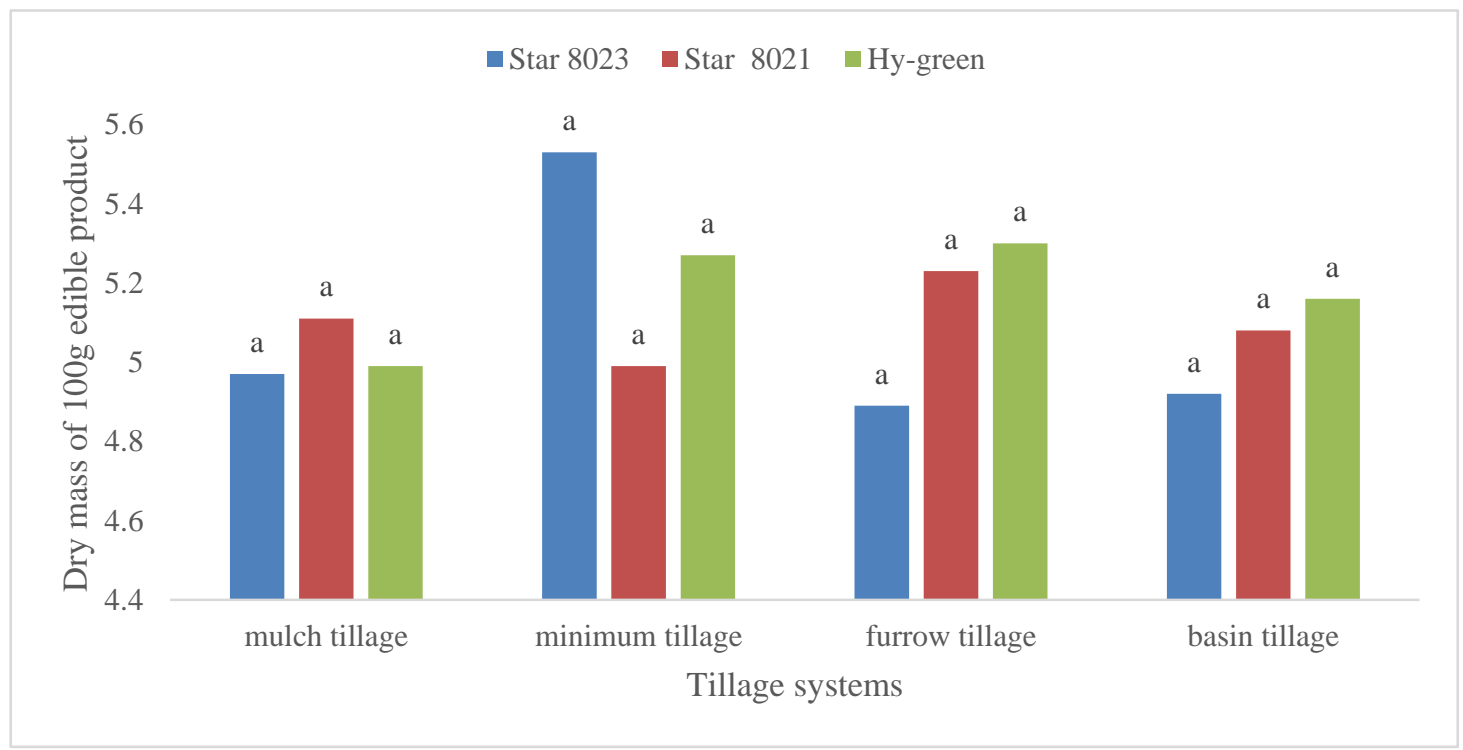

Figure 3. Effects of different tillage systems on dry matter of zucchini cultivars Star 8023, Star 8021 and Hy-green. Bars for each parameter followed by same letter not significantly different from each other at $P$ $=0.005$. Mean separation by DNMRT

\subsection{Mineral Contents}

\subsubsection{Calcium}

There were no significant $(\mathrm{P}>0.05)$ differences in the calcium content in the fresh sample of zucchini amongst all treatments (Figure 4). The highest calcium content $(24.6 \mathrm{mg}$ ) per $100 \mathrm{~g}$ edible product was recorded in plants under basin till while the lowest $(23.8 \mathrm{mg}$ ) was obtained from plants grown in minimum tillage system. For the cultivar Star 8021, the highest calcium content $(24.6 \mathrm{mg})$ per $100 \mathrm{~g}$ edible product was recorded in plants grown under minimum tillage while furrow tillage had the lowest $(23.9 \mathrm{mg}$ ) (Figure 4). Plant under basin tillage system obtained the second highest calcium content edible product. In cultivar Hy-green, the highest calcium content $(24.8 \mathrm{mg})$ was obtained in plants under minimum tillage while the lowest $(24.4 \mathrm{mg})$ was observed in plants under mulch system. Plants grown under basin tillage system obtained the second highest calcium content. 


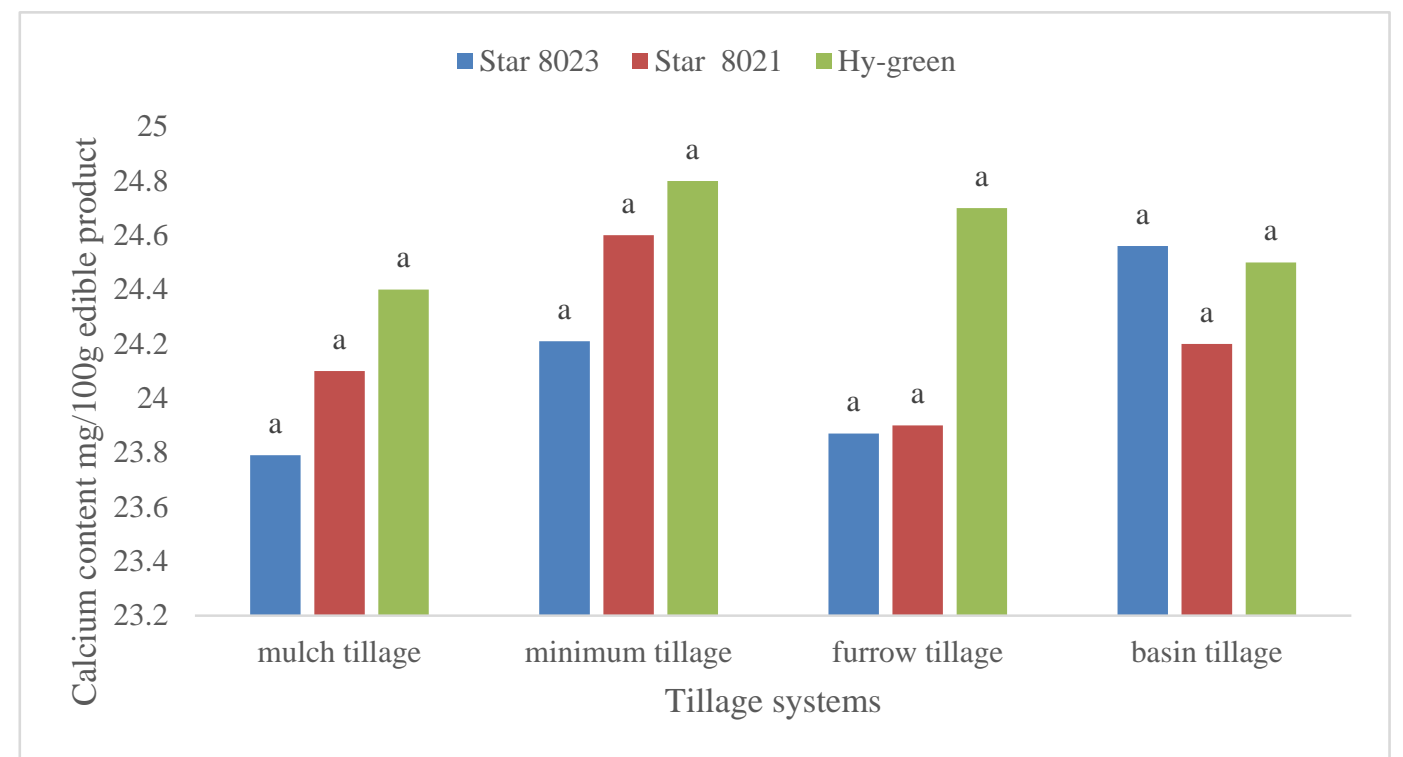

Figure 4. Effects of different tillage systems on calcium content of zucchini cultivars Star 8023, Star 8021 and Hy-green. Bars for each parameter followed by same letter not significantly different from each other at $\mathrm{P}$ $=0.005$. Mean separation by DNMRT

\subsubsection{Iron}

There were no significant $(\mathrm{P}>0.05)$ differences in the iron content in the fresh sample of zucchini amongst all treatments (Figure 5). In cultivar Star 8023, the highest iron content $(0.7 \mathrm{mg})$ per $100 \mathrm{~g}$ edible product was recorded in plants under furrow tillage while the lowest $(0.6 \mathrm{mg})$ was obtained from plants grown in basin tillage system. For the cultivar Star 8021 , the highest iron content $(0.7 \mathrm{mg})$ was recorded in plants grown under minimum tillage while basin tillage obtained the lowest $(0.6 \mathrm{mg})$. In cultivar Hy-green, the highest iron content $(0.7 \mathrm{mg})$ was obtained in plants under mulch tillage while the lowest $(0.6 \mathrm{mg})$ was observed in plants under minimum tillage system.

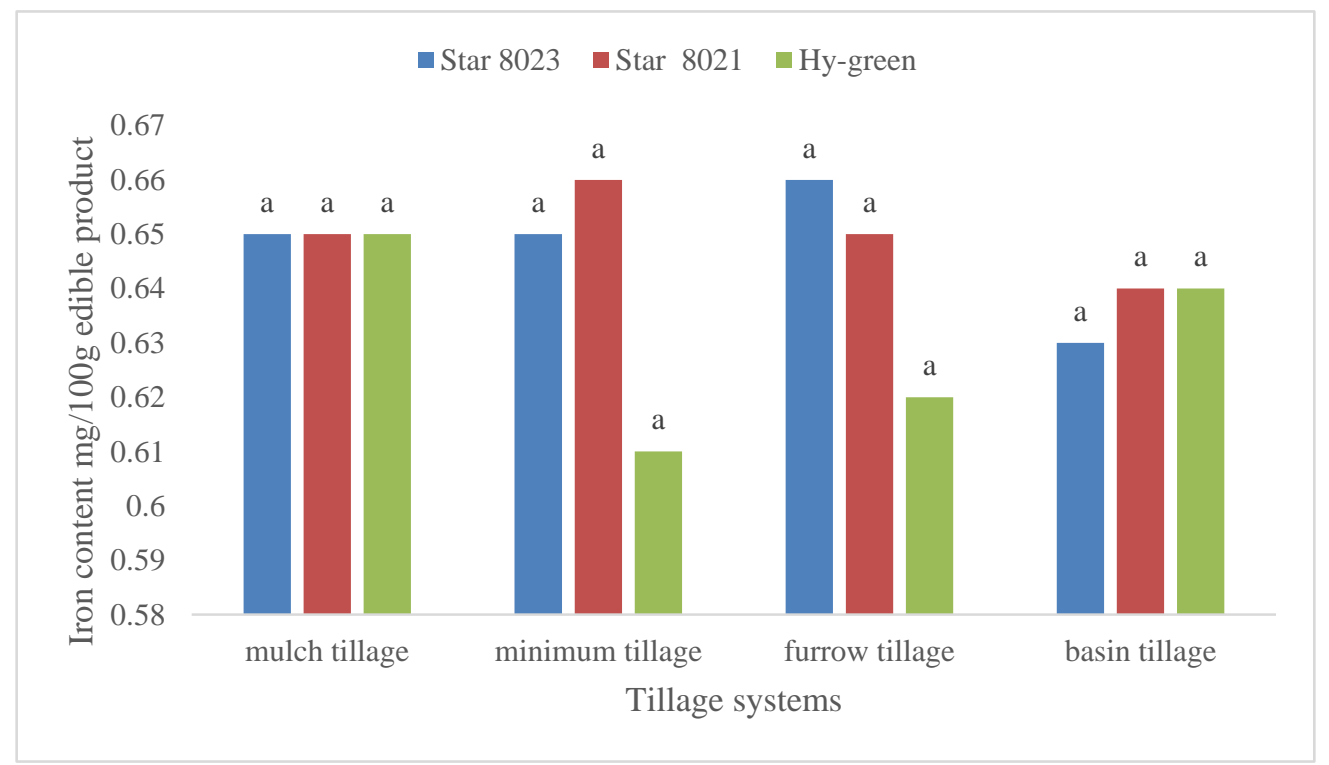

Figure 5. Effects of different tillage systems on iron content of zucchini cultivars Star 8023, Star 8021 and Hy-green. Bars for each parameter followed by same letter not significantly different from each other at $P$ $=0.005$. Mean separation by DNMRT 


\section{Discussion}

This study established that zucchini plants that were grown under basin, mulch and furrow tillage systems exhibited vigorous growth in terms of plant height, number of leaves and leaf area index. Plants grown under minimum tillage showed least vegetative growth vigour. This could probably be due to inability of the zucchini roots to penetrate the heavy unloosened soil. Minimum tilled soils are usually bulky and have poor soil composition (Teresa and Harry., 2016). Soil serves the needs for plant by providing water, air and nutrients. Compactness of the soil reduces the soil aeration and plant provision for oxygen which is very essential for growth of plants.

In contrast, Ewansiha et al. (2015) reported tallest cowpeas under minimum tillage when compared to ridge and basin tillage systems. This was attributed to the fact that the soil that was used in that study had higher percentage of sand (84\%) and was characterised as sandy loam while the soil that was used in this study was loam soil with just about $25 \%$ sand and is adjudged no to be loose enough to enable crop performance without tilling.

A study by Sobeih (2004) showed that roots may sense difficult conditions in the soil and send inhibitory signals to the shoots which harden the plants and the penetration of roots is inhibited as compared to well loosened soils. Hassayon (2009) reported that before planting of zucchini seed the soil should be well loosened to mix well with the soil and all residues from the previous crop should be well rotted. A root barrier in bulky soils is a key attribute which mainly affects the depth of soil available for roots to extract water and nutrients as well as soil porosity. Any form of stress in the roots can significantly reduce growth (Sobeih, 2004).

The study also showed that there were significant differences in yields between the tillage systems. Plants under minimum tillage system had lower yields. This could probably be attributed to lower LAI of plants grown under zero tillage system. Highest LAI helps improve the interception of sunlight which eventually increases the amount of assimilates for plant storage (De Koning, 1994). Heuvelink (1999) reported higher marketable yield in tomato where the LAI is kept higher than when it is reduced by removing most of the older leaves. Studies by African Conservation Tillage Network (2008) showed that minimum tillage systems produce less yields at the initial stages and the nutrients tend to build up over time. There were no significant differences in yield of plants between the furrow, basin and mulch systems but basin tillage system had slightly higher yields.

In cultivar 8023 , zero tillage was superior to the other tillage system in total dry matter yield but the differences were not significant. The lowest dry matter was recorded from plants in the mulch system. These results are in agreement with those of Ewanisha et al (2015) who recorded higher dry matter in cowpeas in zero tillage. However, Madamba et al. (2006) reported lower dry matter in cowpeas under minimum tillage systems. Studies by Muller and Garnier (1990) recorded highest total dry matter in wheat-grass under highly tilled system.

Hy-green cultivar tended to perform better than the Star 8023 and Star 8021 probably because both these cultivars are winter varieties (Starke Ayres, 2018). For Star 8023, the number of fruits harvested per day tended to peak at 8 WAP. This could probably be because Star 8023 is a medium maturing variety as compared to Star 8021 and Hy-green both known as early maturing varieties.

This research has established that there was no considerable variation in the fruit dry matter of zucchini observed amongst treatment. Based on 100g edible product of fruit, tillage method had no significant effect in the calcium and iron content of zucchini. Magkos et al. (2003) reported that there was no significant difference in uptake of minerals such as calcium, phosphorus, zinc and copper between conventional and conservation method of tillage.

\section{Conclusion}

From this study, it can be concluded that zucchini grown using the basin, mulch and furrow tillage systems exhibited vigorous growth (number of leaves, plant height and leaf area index) number of flowers and fruits and yield when compared to the minimum tillage system. The highest vegetative growth was obtained in basin tillage and under cultivar Hy-green. The quality of the crop (dry matter, calcium and iron contents) was not affected by either the tillage system or the cultivar used (Star 8023, Star 8021 and Hy-green variety). Minimum tillage system obtained a slightly high quality. Cultivar 8021 obtained a slightly higher quality. Cultivar Star 8023 obtained the highest yield than both Hy-green which was Star 8021 which had the least.

\section{Acknowledgement}

I would like to extend my sincere gratitude to Prof. M.T. Masarirambi and Prof. P. K. Wahome for their supervision, patience, encouragement and guidance throughout the research work. I would also like to acknowledge those people who supported me towards the completion of my work, who include: Mr. Edward Lulane from the Malkerns Research Station. 


\section{References}

Abdalla, M. A., \& Mohamed, A. E. (2007). The response of two-sorghum cultivars to conventional and conservation tillage systems in central Sudan. AMA - Agric. Mech. Asia. African and Latin American Journal, 38, 67-71. https://doi.org/10.2134/agronj1981.00021962007300020001x

Affholder, F., \& Jourdain, D. (2008). Eco-intensification dans les montagnes du Vietnam. Contraintes à l'adoption de la culture sur couverturesvégétales. Cahiers Agri., 17, 289-296. https://doi.org/10.1684/agr.2008.0199

African Conservation Tillage Network, (2008). 26 June 2015. http://www.act-africa.org

Agriculture and Food Partnership (2016). 12 June 2017. https//dx.doi.org/10.1787/agr.12-06-2017

Benites., J. R., \& Ashburner, J. E. (2003). FAO'S role in promoting conservation agriculture. Zurich, Switzerland Conservation Agriculture. Environment Farmers Expo Innovation and Socio-Econ Policy, 2, 139-153. https://doi.org/101007/978-94-017-1143-2_17

Bolliger, A. (2007). Is Zero-till an appropriate agricultural alternative for disadvantaged smallholders of South Africa?. A study of surrogate systems and strategies, smallholder sensitivities and soil glycoproteins (Doctoral Dissertation). University of Copenhagen, Copenhagen, Denmark

Bolliger, A., Magid, J., Amado, J. C., Neto, F. S., Ribeiro, D. D., Calegari, A., Ralisch, R., \& de Neergaard, A. (2006). Taking stock of the Brazilian "zero-till revolution": A review of landmark research and farmers' practice. Advanced Agronomy, 23, 421-428. http://doi.org/10.1016/j.apsoil.2007.03.006

De Koning, A. (1994). Development and dry matter distribution in greenhouse tomato; a qualitative approach. (Doctoral Dissertation), Wageningen Agriculture University, Wageningen, Netherlands.

Erenstein, O. (2002). Crop residue mulching in tropical and semi-tropical countries: an evaluation of residue availability and other technological implications. Soil Tillage Research Journal, 67, 115-133. https://doi.org/10.1016/S0167-1987(02)00062-4

Eswatini Meteorological Department. (2018). www.swazimet.org

Ewansiha, S., Kamara, Y., \& Udensi, U. (2015). Effect of tillage on growth and yield of cowpeas variety in Sudan Savanna Agroecology of Northern Nigeria. Annual Research and review in Biology, 5(3), 275-284. https://doi.org/10.9734/arr/2015/11694

FAO (2008a). Investing in Sustainable Agricultural Intensification. The Role of Conservation Agriculture. A Framework for Action. Food and Agriculture Organization of the United Nations, Rome. Retrieved from http//hdl.handle.net/10919/68185

FAO, (2008). Conservation Agriculture in Central Asia. 08 July 2018. https//doi.org/10.1016/j.fcr.2012

Food and Agriculture Organization Annual Report (2001), Agriculture and Consumer Protection Department. Rome, Italy. Retrieved from https://doi.fao.org/10.1007/82_2001_62 .04-03-2017

Fowler, R., \& Lockström, J. (2001). Conservation tillage for sustainable agriculture an agrarian revolution gathers momentum in Africa. Soil Tillage Research Journal, 67, 123-131. https://dx.doi.org/10.1016/S0167-1987(02) 00062-4

Gaj, R., Budka, A., \& Przyybyl, J. (2015). Effects of Different tillage systems on the macronutrient content an uptake in sugar beets. Journal of Elememetary Science, 20(4), 839-855. https://doi.org/10.5601/jelem.2015.20.1.817

Gomez, K. A., \& Gomez, A. A. (1984). Statistical Procedure for Agricultural Research. $2^{\text {nd }}$ edition. John Wiley and Sons, Singapore.

Gowing, J. W., \& Palmer, M. (2008). Sustainable agricultural development in sub-Saharan Africa: the case for a paradigm shift in land husbandry. Journal of Soil Use and Management, 24, 92-99. http://doi.org/10.1111/j.1475-2743.2007.00137.x

Gupta, R., Hobbs, P. R., \& Sayre, K. (2007). The role of conservation agriculture in sustainable agriculture. The Royal Society Publishing, London, United Kingdom. https://doi.org/10.1098/rstb.2007.2169

Hassayon, D. G. (2009). The Vegetable and Herb Expert. Expert book. Macmillan publishers, London, UK.

Hebblethwaite, J., Soza, R., Faye, A., \& Hutchinson, N. (1996). No-till and reduced tillage for improved crop production in sub-Saharan Africa. Achieving greater impact from research investments in Africa. Addis 
Ababa.

Heuvelink, E. (1999). Evaluation of dynamic simulation model for tomato crop growth and development. Annal Journal of Botany, 77, 71-80. https://doi.org/10.1006/anbo.1998.0832

Hobbs, P. R. (2007). Conservation agriculture: what is it and why is it important for future sustainable food production?. Journal. Agricicultural Science., 145, 127-137. https://doi.org/10.1017/S0021859607006892

Lahmar, R. (2009). Adoption of conservation agriculture in Europe: lessons of the KASSA project. Land Use Policy. https://doi.org/10.1016/j.landusepol.2008.02.001

Madamba, R., Grubben, I., \& Akromah, B. (2006). Vigna unguiculata (L) Walp. Record from Protabase, PROTA (Plant Resource of Tropical Africa). https://doi.dx.10.1111/j.1745-45557.2006.00083.x

Magkos, F., Arvaniti, F., \& Zamplelas, A. (2003). Organic food. Nutritious food or food for thoughts? A review evidence. International Journal Food Science and Nutrition, 54, 357-371. https://doi.org/10.1080/09637480120092071

Mlipha, M. (2010). The introduction and practice of conservation agriculture in Swaziland. UNISWA Journal of Agriculture, 5, 225-241.

Muller, B., \& Garnier, E. (1990). Components of relative growth rate and sensitivity to nitrogen availability in annual and perennial species of Bromus. Journal of Oecologia, 84, 513-518. https://doi.org/10.1007/BF00328168

National Agriculture Marketing Board annual report (2016). http://doi.org/10.1080/03057070.2016

Oladeebo, J. O. (2013). Does conservation agriculture matters in Swazis' economy? Evidence from maize producing farmers in Ngwempisi Rural Development Area of Swaziland. Journal of Enviromental Science, 3 , 79-85. https:/dx.doi.org/10.25157/ma.v3i2

SAS (2013). Statistitical Analysis Software. SAS Institute, Cary, North Carolina State. http//dx.doi.org/10.13070/mm.en.4.1282

Sobeih, L. (2004). Rhizosphere manipulation to maximize 'crop drop' during deficit irrigation. Journal Experimental Botany, 60, 2454-2459. https://doi.org/10.1093/jxb/erp192

Starke Ayres (2018). Squash zucchini. https//doi.org/10.5281/zenodo.88661525-01-2019

Teresa, A., \& Harry, S. (2016). Italian horticultural and culinary records of summer squash (Cucurbita pepo Cucurbitaceae) and emergence of the zucchini in 19th-century Milan. Annal Journal of Botany, 118, 53-69. https://doi.org/10.1093/aob/mcw080

Tittonell, P., Vanlauwe, B., Leffelaar, P., Rowe, C., \& Giller, K. (2008). Exploring diversity in soil fertility management of smallholder farms in western Kenya. Heterogeneity at region and farm scale. Journal of Agriculture Ecosystems and Environment, 110, 149-165. https://doi.org/10.1016/j.agee.2005.04.001

Triplett, G. B., \& Warren, A. D. (2008). No-Tillage crop Production: A Rev in Agriculture. Agronomy Journal, 100(3), 172-181. https://doi.org/10.2134/agronj2007.0005c

Xiaolei, S., \& Zhifeng, W. (2004). The optimum leaf area index for cucumber photosynthesis and production in plastic glass house. ActaHort. https://doi.org/10.17660/ActaHortic.2004.633.19

\section{Copyrights}

Copyright for this article is retained by the author(s), with first publication rights granted to the journal.

This is an open-access article distributed under the terms and conditions of the Creative Commons Attribution license (http://creativecommons.org/licenses/by/4.0/). 